УДК 615.849.2

DOI https://doi.org/10.11603/2312-0967.2020.1.10980

\title{
МАРКЕТИНГОВІ ДОСЛІДЖЕННЯ АСОРТИМЕНТУ КОНТРАСТНИХ ЛІКАРСЬКИХ ЗАСОБІВ, РЕПРЕЗЕНТОВАНИХ НА ФАРМАЦЕВТИЧНОМУ РИНКУ УКРАЇНИ
}

\author{
Т. А. Пальчевська, О. П. Баула, О. О. Салій, В. І. Бессарабов, Г. В. Тарасенко, \\ Г. Г. Куришко
}

Київський національний університет технологій та дизайну

palchevska_knutd@ukr.net

ІНФОРМАЦІЯ

Надійшла до редакції / Received:

27.11.2019

Після доопрацювання / Revised: 15.01.2020

Прийнято до друку / Accepted: 17.01.2020

\section{Ключові слова:}

маркетингові дослідження, контрастні лікарські засоби; фрірма-виробник;

активний фрармацевтичний інгредієнт:

допоміжні речовини.

\section{АНОТАЦІЯ}

Мета роботи. Провести аналіз вітчизняного фрармацевтичного ринку контрастних лікарських засобів (КЛЗ); встановити обсяг асортиментних позицій вітчизняних виробників та визначити домінуючий сегмент за якісним складом досліджуваних ЛЗ.

Матеріали і методи. Аналіз проводили на основі даних Державного реєстру лікарських засобів України, електронних баз даних, інформаційнопошукової програми «Моріон» станом на 2019 рік. Отримані дані досліджень опрацьовували методами узагальнення, систематизації, графрічного, порівняльного та структурного аналізу.

Результати й обговорення. Встановлено, що до групи зареєстрованих КЛЗ відноситься 36 найменуваннь, 3 них 31 Л3 належать до йодовмісних Кл3 (5 Л3 - йонні, 26 Л3 - нейонні), 5 препаратів складають контрастні засоби на основі гадолінію та барію.

Лідером імпортних препаратів є фрірма-виробник і заявник Юнік Фармасьютикал Лабораторіз, Індія, частка якої складає 27,8 \%. Обсяг вітчизняного асортиментного сегмента знаходиться на рівні 33,4 \%, провідне місце серед вітчизняних виробників посідає фрармацевтичне підприємство ПАТ «Фармак».

Вивчено структуру асортименту досліджуваної групи за торговельними назвами (ТН) та країнами-виробниками: загальна кількість ТН становить 17 найменувань КЛ3, із них 5 TH - лікарські засоби вітчизняних фрармацевтичних підприємств. До основного складу досліджених контрастних ЛЗ входить 10 активних фрармацевтичних інгредієнтів (АФІ), а також такі допоміжні речовини, як трометамол і/або трометамін та меглюмін, що сприяють зменшенню негативної реакції на організм людини та покращують загальні властивості КЛЗ.

Висновки. Встановлено, що український ринок КЛЗ фрормується, в основному, за рахунок імпортних л3, їх питома вага складає 66,6 \%.

Встановлено відсутність вітчизняного виробництва нейонних йодовмісних КЛЗ: йопромід, йодиксанол.
Вступ. Фармацевтичний ринок - один із найбільш динамічних ринків лікарських засобів як у світі, так і в Україні. Сьогодення характеризується розширенням асортименту срармацевтичної продукції, яка виходить на ринок [1].
Швидке зростання рівня ракових захворювань та серцево-судинних розладів потребують медичної візуалізації для встановлення стану пацієнта на різних стадіях лікування. Застосування таких новітніх техно-

ISSN 2312-0967. Фармацевтичний часопис. 2020. № 1 
логій, як комп'ютерна та магнітно-резонансна томограсрії (КТ та МРТ), ультразвукова діагностика (УЗД) збільшують попит у контрастних лікарських засобах. Однак такі фрактори, як побічні реакції і навіть тяжкі реакції, які потребують екстреної терапії, з одного боку, стримують застосування контрастних засобів та зростання ринку, з іншого - ініціюють пошук нових продуктів із удосконаленою технологією, якістю та новими можливостями [2].

У роботі висвітлено маркетингові дослідження асортименту КЛЗ на ринку України. В сучасній променевій діагностиці від своєчасного і грамотного застосування контрастних препаратів залежить не тільки точність діагнозу, але й оцінка динаміки процесу і результатів лікування. Одним з універсальних методів діагностики захворювань $€$ штучне контрастування для виявлення найменших відхилень в організмі людини. В медичній практиці широко застосовують рентгеноконтрастні засоби, що затримують рентгенівське випромінювання, це КЛЗ на основі йодовмісних активних фрармацевичних інгредієнтів (АФІ), а також КЛЗ, що не містять йод.

Відповідно до анатомо-терапевтично-хімічної (ATX) класифрікації ВОО3 КЛ3 належать до групи V різні засоби; фрармакотерапевтична група коду: VO8 - контрастні засоби, V08A - йодовмісні ренгеноконтрастні засоби; V08AA - водорозчинні високоосмолярні нефротропні рентгеноконтрастні засоби (йонні); V08AB - водорозчинні низькоосмолярні несротропні рентгеноконтрастні засоби (нейонні); V08B рентгеноконтрастні засоби, що не містять йод; V08CA - контрастні засоби для ЯМР-томограсрії.

Питання забезпечення населення якісними та безпечними лікарськими засобами залишається одним із пріоритетних напрямів діяльності Міністерства охорони здоров'я України. Прогнозування подальшого розвитку вітчизняного ринку стосовно КЛЗ $є$ актуальним питанням охорони здоров'я на Україні. За результатами системного аналізу сучасних спеціальних літературних джерел за останні 15 років встановлено, що у зв'язку з розвитком рентгенології КЛЗ широко застосовуються в багатьох галузях охорони здоров'я населення. Позитивний досвід застосування у діагностиці мають йоногенні КЛЗ тріомбраст, урографрін та тразографр, що містять активний йоногенний фрармацевтичний інгредієнт - натрію амідотризоат. В урології урограсрін залишається одним 3 найбільш вживаних ЛЗ [3]. Вимоги до якості активного фрармацевтичного інгредієнта - натрію амідотризоату, наведені в монографії Державної Фармакопеї України 2-го видання [4]. Спостерігається прогресивне зниження загальної токсичності нейонних йодовмісних внутрішньосудинних позаклітинних КЛЗ та, як наслідок, зниження числа побічних реакцій при їх використанні в ревматології. Використання Омніпаку у різних концентраціях (Омніпак-300, Омніпак-270, Омніпак-180) сприяє уточненню рівня компресії при діагностиці кістково-суглобового туберкулезу. Концепція створення рентгеноконтрастних засобів нового покоління націлена на рентгеноконтрастні речовини з магнітокерованими властивостями [5].

Аналіз публікацій за останні роки довів відсутність маркетингових досліджень динаміки розподілу асортименту КЛ3 групи VO8 на вітчизняному фармацевтичному ринку. Отже, визначення суттєвих питань щодо домінуючого сегмента на ринку контрастних засобів, структурного аналізу асортименту ЛЗ за анатомо-терапевтично-хімічною (АTX) класифрікацією, кількістю діючих речовин, видом лікарської фрорми є актуальним напрямком досліджень для обґрунтування доцільності розробки нових малотоксичних вітчизняних лікарських препаратів.

Мета роботи - провести аналіз вітчизняного фармацевтичного ринку КЛЗ, встановити обсяг асортиментних позицій вітчизняних виробників та визначити домінуючий сегмент за якісним складом досліджуваних ЛЗ.

Матеріали і методи. Аналіз проводили на основі даних Державного реєстру лікарських засобів України, електронних баз даних, інформаційно-пошукової програми «Моріон» станом на 2019 рік. Отримані дані досліджень опрацьовували методами узагальнення, систематизації, графрічного, порівняльного та структурного аналізу [6].

Результати й обговорення. За результатами аналізу інсрормаційних джерел [7-9] встановлено, що на вітчизняному фрармацевтичному ринку на сьогодні зареєстровано 36 КЛЗ. Аналіз структури асортименту КЛЗ за лікарськими формами підтвердив, що основна їх частка -94 \% - представлена у вигляді розчину для ін'єкцій (та/або для інфузій) та 6 \% - у срормі порошку барію сульфату для його подальшого перорального застосування у вигляді суспензії. На фрармацевтичний ринок барію сульфат для рентгеноскопії постачають такі вітчизняні фрірми-виробники, як ТОВ «Істок-Плюс» та ТОВ «Фармацевтична компанія «Здоров'я».

Аналіз розподілу всіх контрастних лікарських засобів за групами класифікації ATX V08 показав, що найбільше КЛ3 (86 \%) належать до йодовмісних рентгеноконтрастних лікарських засобів, 3 них нейонні КЛЗ складають $72 \%$ та йонні - $14 \%$; ЛЗ без йоду $\left(\mathrm{BaSO}_{4}-6\right.$ \%) і сегмент інші КЛ3 - 8 \% - до парамагнітних контрастних засобів (рис. 1).

Невелику частку за обсягом йоних йодовмісних КЛ3 (14 \%) можна пояснити високою осмолярністю даних лікарські засоби, тому їх застосування супроводжується появою ряду небажаних побічних ефектів в організмі людини: гіпотонією, нефропатією, збільшенням проникності капілярів, болючістю судин, нудотою тощо.

У 80-ті роки минулого сторіччя були впроваджені в практику стабільні трийодовані нейонні КЛ3, на діаграмі їх сегмент асортименту найбільший (72 \%),

ISSN 2312-0967. Pharmaceutical review. 2020. № 1 
Фармацевтичний менеджмент, маркетинг та логістика

Pharmaceutical management, marketing and logistics

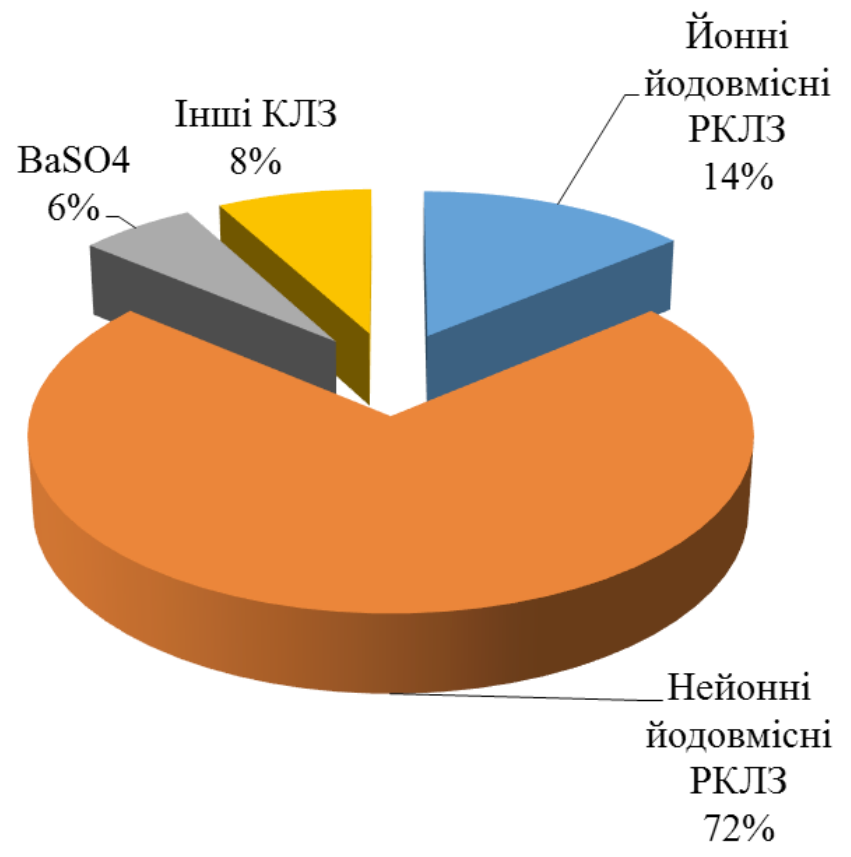

Рис. 1. Розподіл КЛЗ за групами класифрікації АTX V08.

тому що вони дають кращі результати з точки зору діагностичної ефективності та безпеки, наприклад, такі відомі трийодозаміщені КЛЗ: йогексол, ультравіст, омніпак, юніпак, томогексол тощо [10-13].

Незважаючи на більш низьку токсичність та кращу переносимість в Україні нейонні КЛЗ поки не витіснили повністю йонні препарати через їхню високу вартість. Тому і сьогодні йонні трийодозаміщені КЛЗ: тріомбраст, урографрін, тразографр широко використовують у медичній практиці.
Проведено систематичний аналіз асортименту досліджуваної групи лікарських засобів за фрірмами-виробниками та країнами походження. Аналіз структури КЛЗ за країнами походження встановив, що на фрармацевтичному ринку України представлені імпортні лікарські засоби із 6 країн-виробників: Індії, Німеччини, Ірландії, Італії, Австрії та Іспанії. Дані розподілу асортименту приведено в таблиці 1. На базі даних таблиці 1 та рисунка 2 представлено розподіл асортиментних позицій КЛЗ між фірмами-виробниками.

\section{Таблиця 1}

Аналіз асортименту досліджуваної групи контрастних лікарських засобів за країнами-виробниками

\begin{tabular}{|c|c|c|c|}
\hline № & $\begin{array}{l}\text { Фірма-заявник, } \\
\text { власник РП, країна }\end{array}$ & Країна-виробник/ фрірма-виробник & $\begin{array}{l}\text { Кількість } \\
\text { КЛ3 }\end{array}$ \\
\hline 1 & \multicolumn{2}{|c|}{$\begin{array}{l}\text { «Юнік Фармасьютикал Лабораторіз» (відділення фрірми «Дж. Б. Кемікалз енд Фармасьютикалз } \\
\text { Лтд.») Індія }\end{array}$} & 10 \\
\hline 2 & $\begin{array}{l}\text { - ПАТ «Фармак»; } \\
\text { - ТОВ «Істок-Плюс»; } \\
\text { - ТОВ Фармацевтична компанія «Здоров'я», Україна }\end{array}$ & $\begin{array}{l}\text { Україна/ } \\
\text { Німеччина } \\
\text { (Solupharm Pharmazeutische Erzeugnisse } \\
\text { GmbH) }\end{array}$ & $10^{*}$ \\
\hline 3 & Байєр АГ, Німеччина & $\begin{array}{l}\text { Німеччина (Байєр АГ, Солюфарм } \\
\text { Фармацеутіше Ерцойгніссе ГмбХ) } \\
\text { Іспанія (БерліМедС.А.) }\end{array}$ & $3+2+1$ \\
\hline 4 & ДжиІ Хелскеа АС, Норвегія & $\begin{array}{c}\text { Ірландія } \\
\text { (ДжиІ Хелскеа Лімітед) }\end{array}$ & 4 \\
\hline 5 & Бракко Імеджінг С.П.А., Італія & $\begin{array}{c}\text { Італія } \\
\text { (Патеон Італія С.П.А.) }\end{array}$ & 4 \\
\hline 6 & М. Біотек Лімітед Велика Британія & Австрія (Санохемія Фармацевтика АГ) & 2 \\
\hline
\end{tabular}

Примітка. * - у виготовленні двох препаратів томоскан (300мг йоду/мл) та томоскан (370 мг йоду/мл) беруть участь 2 країни-виробники: Україна та Німеччина (ПАТ «Фармак», проводить пакування із фрорми in bulk фрірми-виробника Solupharm Pharmazeutische Erzeugnisse $\mathrm{GmbH}$, Німеччина).

ISSN 2312-0967. Фармацевтичний часопис. 2020. № 1 
Фармацевтичний менеджмент, маркетинг та логістика Pharmaceutical management, marketing and logistics

"Юнік Фармасьютикал Лабораторіз" (відділення фірми "Дж. Б. Кемікалз...

ТОВ "Істок-Плюс", Україна

ТОВ Фармацевтична компанія "Здоров'я", Україна

ПАТ "Фармак", Україна

БерліМедС.А., Іспанія

Патеон Італія С.П.А., Італія

Санохемія Фармацевтика АГ, Австрія

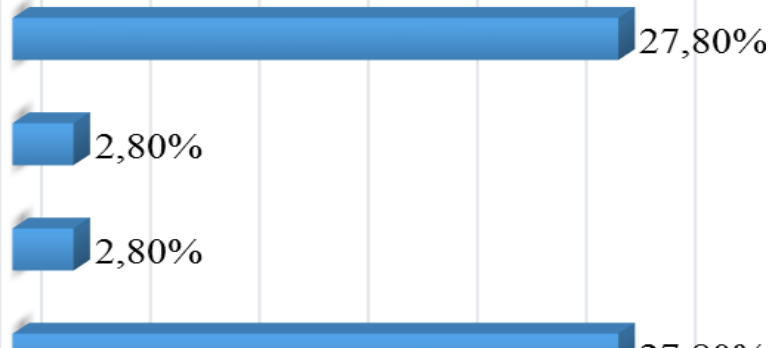

ДжиІ Хелскеа Ірландія Лімітед,.

Байєр АГ, Німеччина

\section{Солюфарм Фармацеутіше Ерцойгніссе ГмбХ Німеччина}

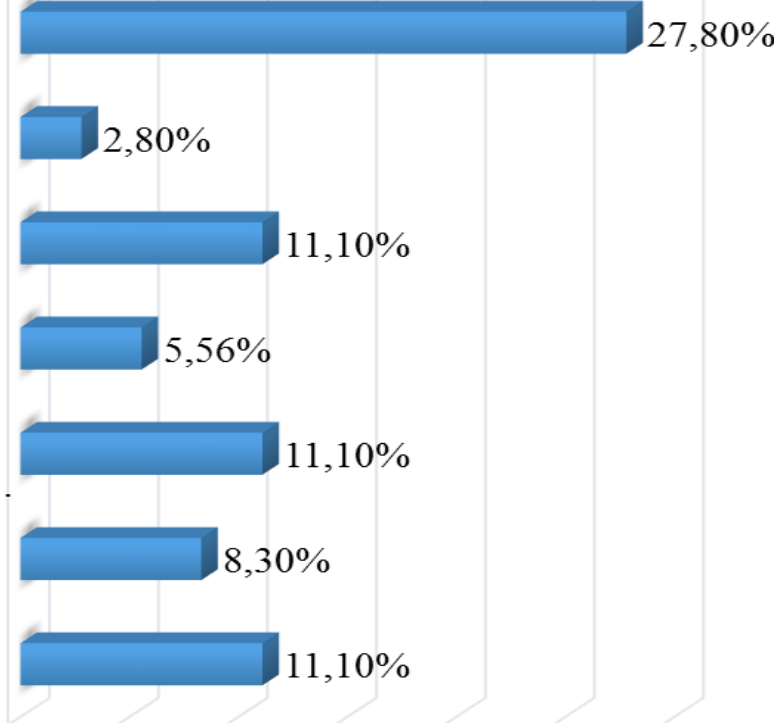

Рис. 2. Розподіл асортиментних позицій КЛЗ між фрірмами та країнами-виробниками.

Дані таблиці 1 та рисунка 2 підтверджують, що 36 лікарських препаратів досліджуваної фрармакотерапевтичної групи на ринок України постачають 7 іноземних та 3 вітчизняні фрірми-виробники.

Встановлено, що обсяг вітчизняного асортиментного сегмента знаходиться на рівні 33,4 \%. Загальна кількість імпортних препаратів на ринку України складає 66,6 \%, що значно переважає асортимент вітчизняних лікарських засобів. Лідером імпортних препаратів є фрірма-виробник - Юнік Фармасьютикал Лабораторіз, (відділення фрірми Дж. Б. Кемікалз енд Фармасьютикалз Лтд.) Індія. Серед вітчизняних виробників - місце лідера за кількістю асортиментних позицій, що виробляються, посідає ПАТ «Фармак» (4 ТН). Сьогодні фрармацевтична фрірма виробляє такі йодоконтрастні препарати, як тріомбраст, томогексол, томоскан та КЛЗ без йоду для ЯМР-томографрії - дотавіст, виробництво яких здійснюється відповідно до вимог належної виробничої практики (GMP), європейських вимог якості Л3, і знаходять широке застосування в медичній практиці при внутрішньовенній та ретроградній урографіії, артрографії, ангіографрії, для досліджень шлунково-кишкового тракту, для контрастного посилення МРТ спинного та головного мозку; МРТ тіла, включно візуалізацію патології серця, нирок, органів черевної та грудної порожнини.
Аналіз зареєстрованих в Україні лікарських засобів за торговельними назвами (TH) показав, що їх загальна кількість становить 17 TH, 13 з них ТН належать до йодовмісних препаратів, $4 \mathrm{TH}$ - препарати без йоду. Необхідно, що для 10 КлЗ від вітчизняних орармацевтичних підприємств використовується 5 $\mathrm{TH}$.

Розподіл Клз за торговельними назвами приведено на рисунку 3.

Найбільше препаратів із торговельними назвами - юніпак (29,4 \%) та томоскан (23,5\%), менше 3 ТН препаратів: урографрін, йодиксанол-юнік, дотавіст, мультіханс та гадовіст (5,8 \%).

На наступному етапі роботи проведено аналіз якісного складу КЛЗ. Перелік основних діючих активних фрармацевтичних інгредієнтів (АФІ) та допоміжних речовин наведено в таблиці 2. Визначено, що до складу КЛЗ входить 10 АФІ, з них 6 - до йодованих КЛЗ, 3 - до КЛЗ на основі гадолінію, один - до КЛЗ на основі барію.

Отже, сегмент йодовмісних КЛЗ займає найбільшу частку ринку.

Водночас проблема безпеки використання КЛЗ залишається досить актуальною. За даними таблиці 2 видно, що більшість КЛЗ, крім активно діючих речовин, містять допоміжні речовини, що мають метаболічну,

ISSN 2312-0967. Pharmaceutical review. 2020. № 1 
Фармацевтичний менеджмент, маркетинг та логістика Pharmaceutical management, marketing and logistics

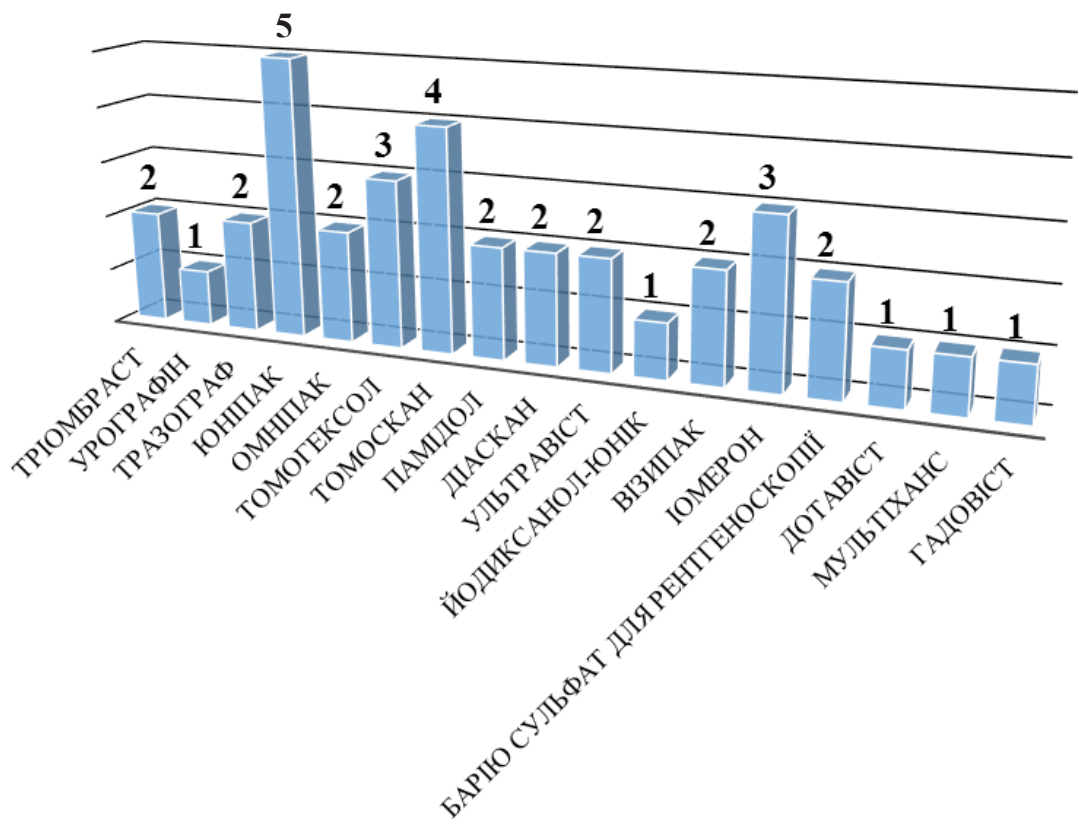

Рис. 3. Розподіл КЛЗ за торговельними назвами.

Таблиця 2

Якісний склад контрастних лікарських засобів

\begin{tabular}{|c|c|c|c|c|}
\hline № & Код АТХ & $\begin{array}{c}\text { Активний фрармацевтичний } \\
\text { інгредієнт }\end{array}$ & Допоміжні речовини & $\begin{array}{l}\text { Кількість } \\
\text { засобів }\end{array}$ \\
\hline \multirow[t]{3}{*}{1} & \multirow[t]{3}{*}{ V08AA01 } & $\begin{array}{l}\text { Діатризоєвої кислоти дигідрат та } \\
\text { меглюміну (N-метилглюкаміну) }\end{array}$ & $\begin{array}{l}\text { Натрію гідроксид, динатрію едетат; вода } \\
\text { для ін'єкцій }\end{array}$ & 2 \\
\hline & & $\begin{array}{l}\text { Натрію амідотризоат та меглуміну } \\
\text { амідотризоат }\end{array}$ & Натрію кальцію едетат, вода для ін'єкцій & 1 \\
\hline & & $\begin{array}{l}\text { Меглумінова сіль діатризойної } \\
\text { кислоти }\end{array}$ & Динатрію кальцію едетат, вода для ін'єкцій & 2 \\
\hline 2 & V08AB02 & Йогексол & $\begin{array}{l}\text { Трометамін / трометамол, двонатрієво- } \\
\text { кальцієва сіль ЕДТА, кислота } \\
\text { хлористоводнева, вода для ін'єкцій }\end{array}$ & 10 \\
\hline 3 & V08AB04 & Йопамідол & $\begin{array}{l}\text { Трометамін / трометамол, двонатрієво- } \\
\text { кальцієва сіль ЕДТА, кислота } \\
\text { хлористоводнева, вода для ін'єкцій }\end{array}$ & 8 \\
\hline 4 & V08AB05 & Йопромід & $\begin{array}{l}\text { Трометамол, двонатрієво-кальцієва сіль } \\
\text { ЕДТА, вода для ін'єкцій }\end{array}$ & 2 \\
\hline 5 & V08AB09 & Йодиксанол & $\begin{array}{l}\text { Трометамол, натрію хлорид, кальцію } \\
\text { хлорид дигідрат, кальцію-натрію едетат, } \\
\text { кислота хлористоводнева, вода для } \\
\text { ін'єкцій }\end{array}$ & 3 \\
\hline 6 & V08AB10 & Іомепрол & $\begin{array}{l}\text { Трометамін; кислота хлористоводнева, } \\
\text { вода для ін'єкцій }\end{array}$ & 3 \\
\hline 7 & V08BA02 & Барію сульфрат & немає & 2 \\
\hline 8 & V08CA02 & Гадотерова кислота & Меглюмін, вода для ін'єкцій & 1 \\
\hline 9 & V08CA08 & Гадобенат димеглуміну & Вода для ін'єкцій & 1 \\
\hline 10 & V08CA09 & Гадобутрол & $\begin{array}{l}\text { Натрію калкобутрол, трометамол, } \\
\text { кислота хлористоводнева, вода для } \\
\text { ін'єкцій }\end{array}$ & 1 \\
\hline
\end{tabular}

ISSN 2312-0967. Фармацевтичний часопис. 2020. № 1 
солюбілізуючу, фрармакотерапевтичну дію, наприклад, меглюмін (N-метилглюкамин) - наповнювач, pH-регулятор та солюбілізатор; трометамол - засіб для корекції ацидозу для парентерального застосування і/або трометамін - бусрерний засіб, солюбілізатор, стабілізатор, які забезпечують ефективність застосування та стабільність препарату протягом терміну зберігання. Згідно з даними літератури допоміжні речовини: меглюмін, трометамол і/або трометамін завдяки їх властивостям значно покращують переносимість контрастних Л3 [13-15].

Встановлено, що в Україні відсутнє виробництво таких нейонних йодовмісних КЛЗ, як йопромід, йодиксанол.

Удосконалення складу КЛЗ сприятиме розробці інноваційних методів діагностичної візуалізації та їх впровадженню в практичну медицину. Вирішення цих завдань сьогодні не втрачає своєї актуальності й має перспективний напрямок в майбутньому.

Висновки. 1. За результатами проведених маркетингових досліджень асортименту КЛЗ на фрармацевтичному ринку України встановлено, що станом на 2019 р. на ринку репрезентовано 36 лікарських засобів для діагностики різних захворювань. Аналіз асортименту досліджуваної групи за лікарськими фрормами показав, що основна їхня частка - $94 \%$ - представлена у вигляді розчину для ін'єкцій та/або для інфрузій.

2. Більшість контрастних лікарських засобів на ринку України становить імпортні препарати, їх питома вага складає 66,6 \%. Лідером за обсягом асортиментних позицій препаратів-імпортерів $€$ Індія, фрірма-виробник і постачальник - Юнік Фармасьютикал Лабораторіз (відділення фрірми Дж. Б. Кемікалз енд
Фармасьютикалз Лтд) - 27,8 \% від загальної кількості препаратів.

3. Встановлено, що українські фрармацевтичні виробники постачають на ринок країни 33,4 \% асортименту контрастних лікарських препаратів, виробником яких $€ 3$ підприємства. Позицію лідера посідає ПАТ «Фармак».

4. Систематичний аналіз зареєстрованих в Україні лікарських засобів за торговельними назвами станом на 2019 р. показав, що їх загальна кількість становить 17 позицій, з них 5 торговельних назв КЛЗ належать вітчизняним фрармацевтичним підприємствам.

5. Встановлено, що йодовмісні КЛЗ займають найбільшу частку ринку асортименту досліджуваної групи, в цілому за рахунок широкого використання при КТ-дослідженнях. 3 10-ти активних фрармацевтичних інгредієнтів 6 належать до йодованих КЛ3, 3 - до КЗ на основі гадолінію та один - до КЛЗ на основі барію.

6. Результати проведеного маркетингового аналізу за країнами-виробниками, фрормою випуску, вмістом діючих компонентів дозволяє зробити висновок, що асортимент вітчизняних препаратів недостатній.

7. Встановлено відсутність вітчизняного виробництва таких нейонних йодовмісних КЛЗ, як йопромід, йодиксанол.

8. Створення нових, сучасних малотоксичних КЛЗ $€$ актуальним завданням для розробки практичних заходів в Україні із підвищення доступності надання фрармацевтичної допомоги хворим при проведенні діагностичних досліджень.

Конфлікт інтересів: відсутній.

Conflicts of interest: authors have no conflict of interest to declare.

\title{
MARKETING RESEARCH ON THE ASSORTMENT OF CONTRAST DRUGS REPRESENTED ON THE PHARMACEUTICAL MARKET OF UKRAINE
}

\author{
T. A. Palchevska, O. P. Baula, O. O. Saliy, V. I. Bessarabov, H. V. Tarasenko, H. H. Kuryshko \\ Kyiv National University of Technologies and Design \\ palchevska_knutd@ukr.net
}

The aim of the work. Conduct an analysis of the domestic pharmaceutical market for contrast drugs (CD); to establish the volume of assortment positions of domestic manufacturers and to determine the dominant segment by the qualitative composition of the investigated drugs.

Materials and Methods. The analysis was conducted on the basis of data from the State Register of Medicines of Ukraine, electronic databases, Morion information search program of 2019. The obtained research data were processed by methods of generalization, systematization, graphical, comparative and structural analysis.

Results and Discussion. It is established that 36 registered names belong to the group of registered contrast medicines, 31 of them refer to iodine-containing X-ray contrast drugs (5 drugs - ionic, 26 drugs - nonionic), 5 drugs make gadolinium and barium contrast media.

The leader in the import of drugs is the manufacturer and the applicant, Unik Pharmaceutical Laboratories, India, whose share is $27.8 \%$. The volume of the domestic assortment segment is at the level of $33.4 \%$, the pharmaceutical company PJSC "Pharmak" is the leading among the domestic manufacturers.

The structure of the assortment of the study group by trade names (TN) and the producing countries was studied: the total

ISSN 2312-0967. Pharmaceutical review. 2020. № 1 
Фармацевтичний менеджмент, маркетинг та логістика

Pharmaceutical management, marketing and logistics

number of TN is $17 \mathrm{CD}$ names, of which 5 TN belong to medicinal products from domestic pharmaceutical enterprises. The main contrast drugs investigated include 10 Active Pharmaceutical Ingredients (AFIs), as well as excipients such as trometamol and/or tromethamine and meglumine, which contribute to the reduction of adverse reactions to the human body and improve the overall properties of CD.

Conclusions. It is established that the Ukrainian CD market is formed mainly due to imported drugs, their share is $66.6 \%$. The absence of domestic production of such CD as non-ionic contrast iodine drugs: iodopromide, iodixanol was established.

Key words: marketing research, contrast drugs; manufacturing firm; active pharmaceutical ingredient; auxiliary substances.

\title{
МАРКЕТИНГОВЫЕ ИССЛЕДОВАНИЯ АССОРТИМЕНТА КОНТРАСТНЫХ ЛЕКАРСТВЕННЫХ СРЕДСТВ, ПРЕДСТАВЛЕННЫХ НА ФАРМАЦЕВТИЧЕСКОМ РЫНКЕ УКРАИНЫ
}

\author{
Т. А. Пальчевская, О. П. Баула, Е. А. Салий, В. И. Бессарабов, Г. В. Тарасенко, Г. Г. Курышко \\ Киевский национальный университет технологий и дизайна \\ palchevska_knutd@ukr.net
}

Цель работы. Провести анализ отечественного фрармацевтического рынка контрастных лекарственных средств (КЛС); установить объем ассортиментных позиций отечественных производителей; проанализировать основной качественный состав исследуемых ЛЗ.

Материалы и методы. Анализ проводили на базе данных Государственного реестра лекарственных средств Украины, электронных баз данных, информационно-поисковой программы «Морион» состоянием на 2019 год. Полученные данные анализировали с помощью методов обобщения, систематизации, графического и структурного анализа.

Результаты и обсуждение. Установлено, что к группе зарегистрированых КЛС относится 36 наименований, из них 31 ЛС - к йодосодержащим КЛС (5 ЛС - ионные, 26 ЛС - неионные), 5 препаратов - контрастные средства на основе гадолиния и бария.

Лидером импортных ассортиментных позиций является фрирма-производитель и заявитель - Юник Фармасьютикал Лабораториз, Индия, доля которой составляет 27,8 \%. Объем отечественного ассортиментного сегмента находится на уровне 33,4 \%, передовые позиции среди отечественных производителей занимает предприятие ЧАО «Фармак». Изучена структура ассортимента исследуемой группы КЛС по торговым названиям (ТН) и странам-производителям: общее количество ТН составляет 17 наименований, из них 5 НТ принадлежит лекарственным средствам от отечественных фрармацевтических предприятий. В основной состав изученных КЛС входит 10 активных фрармацевтических ингредиентов (АФИ), а также вспомагательные вещества (трометамол и /или трометамин, а также меглюмин), которые способствуют уменьшению негативного влияния и улучшают общие свойства КлС.

Выводы. Установлено, что украинский рынок КЛС формируется, в основном, за счет импортных ЛЗ, их удельный вес составляет $66,6 \%$.

Установлено отсутствие отечественного производства неионных йодосодержащих КлС: йопромид, йодиксанол.

Ключевые слова: маркетинговые исследования; контрастные лекарственные средства; фрирма-производитель; активный фармацевтический ингредиент; вспомогательные вещества.

\section{Список бібліографрічних посилань}

1. Про затвердження концепції розвитку фрармацевтичного сектору галузі охорони здоров'я України на 2011-2020 роки : наказ Міністерства охорони здоров'я України від 13.09.2010 р. № 769.

2. Contrast Media/Contrast Agent Market by Type (Iodinated, Gadolinium, Barium, and Microbubble), Procedure (X-Ray/CT, MRI, and Ultrasound), Application (Radiology, Interventional Radiology, and Interventional Cardiology), Region - Global Forecast to 2024.[Електронний ресурс] : Access mode : https://www.marketsandmarkets.com/ Market-Reports /contrast-media-market-911.html.

3. щербинин С. Н., Токарева Е. В., Яровой С. К. Рентгеноконтрастные средства в урологической практике. Экспериментальная и клиническая урология. 2010. № 4. С. 63-66.
4. Державна Фармакопея України : в 3 т. Вид. 2-ге. Харків : Державне підприємство «Український науковий фрармакопейний центр якості лікарських засобів», 2014. Т. 2. С. 469.

5. Концепція створення рентгеноконтрастних засобів нового покоління / Левітін $€$. Я., Панасенко О. І., Коваль А. О., Ведернікова І. О. Актуальні питання фрармацевтичної і медичної науки та практики. 2011. Вип. XXIV. № 3. С. 48-51.

6. Менеджмент і маркетинг у фрармації: підручник (ВН3 IV р. а.) / Громовик Б. П. та ін. ; за ред. Б. П. Громовика. Київ : ВСВ Медицина, 2008. 752 с.

7. Державний реєстр лікарських засобів України 2019 Інформаційний фонд. URL: http://www.drlz.com.ua/ ibp/ddsite.nsf/all/shlist?opendocument

ISSN 2312-0967. Фармацевтичний часопис. 2020. № 1 
8. Довідник лікарських засобів, зареєстрованих в Україні станом на 24.06.2019. URL: https://medhub.info/.

9. Лекарственные средства: база данных ООО «Морион». URL: www.morion.kiev.ua.

10. Hoey G. B., Smith K. R. Chemistry of X-ray contrast media. In: Sovak M, ed. Radiocontrast agents. Handbook of Experimental Pharmacology, Vol. 73. New York: Springer-Verlag; 1984. 23-126.

11. Контрастные средства / Сергеев П. В., Поляев Ю. А., Юдин А. Л., Шимановский Н. Л. Москва : Известия, 2007. 496 C.

12. Сидорова Е. Е., Кармазановский Г. Г. Сравнительное исследование контрастирующих свойств неионных рентгеноконтрастных препаратов йогексол-350 и йоверсол-350 при спиральной компьютерной томограсии у пациентов с гиперконтрастными образованиями печени. Медицинская визуализация. 2007. № 5. С. 106-117.

\section{References}

1. Order of the Ministry of Health of Ukraine "On approval of the concept of Pharmaceutical Sector of Ukraine Health for 2011-2020 as of 13 Sept 2010" from Sept, 2010 No. 769 [Electronic resource]. Available from: https://ips.ligazakon.net/document/view/ moz11951?an=216\&ed=2013_09_30 [Accessed Sept 2010]. Ukrainian.

2. Contrast Media/Contrast Agent Market by Type (Iodinated, Gadolinium, Barium, and Microbubble), Procedure (X-Ray/CT, MRI, and Ultrasound), Application (Radiology, Interventional Radiology, and Interventional Cardiology), Region - Global Forecast to 2024. [Electronic resource]. Available from: https://www.marketsandmarkets.com/Market-Reports/contrast-mediamarket-911.html.

3. Shcherbinin SN, Tokareva EV, Yarovoj SK. [X-ray contrast agents in urological practice]. Eksperimental i klin urologiya. 2010;4: 63-6. Russian.

4. The State Pharmacopoeia of Ukraine: in 3 vol. Kharkiv: Ukrainian Scientific Pharmacopoeial Center for Medicinal Products Quality. Type 2. Vol. 2. [Державна Фармакопея України: в 3 т. / ДП «Український науковий фрармакопейний центр якості лікарських засобів» - 2-е вид. Т. 2.] Kharkiv: Ukrainian Scientific Pharmacopoeial Center for Medicinal Products Quality; 2014. Ukrainian.

5. Levitin Yela, Panasenko OI, Koval AO, Vedernikova IO. [The concept of creation of X-ray contrast drugs of the new generation]. Aktualni pytannia farm i med nauky ta praktyky. 2011;24(3); 48-51. Ukrainian.

6. Hromovyk BP, editor. Pharmacy management and marketing [Менеджмент і маркетинг у фрармації] Kyiv: Medytsyna; 2008. Ukrainian.

7. State Register of Medicines of Ukraine 2019 Information Fund. [Electronic resource]. Available from: http://www. drlz.com.ua/ibp/ddsite.nsf/all/shlist?opendocument Poshuk likarskykh zasobiv. Ukrainian.

8. Handbook of drugs registered in Ukraine as of 24/06/2019. [Electronic resource]. Available from:
13. Хохлов А. Л., Кабанов А. В., Козлова О. Г. Безопасность рентгеноконтрастных веществах: фрокус на безопасность. Медицинская визуализация. 2018. № 5. C. 94-105.

14. Коваленко А. Л. Фармакологическая активность оригинальных лекарственных препаратов на основе 1-дезокси-1(N-метиламино)-D-глюцитола : дисс. д-ра биол. наук. Санкт-Петербург, 2005. URL: https:// www.dissercat.com /content/farmakologicheskayaaktivnost-originalnykh-lekarstvennykh-preparatov-naosnove-1-dezoksi-1n- Ссылка активна на 30 октября 2019

15. Коваленко С. М. Вибір допоміжних речовин при створенні комбінованих таблеток для лікування діабетичних ускладнень. Проблеми екологічної та медичної генетики і клінічної імунології. 2012. Вип. 1. C. 333-340. URL: http://nbuv.gov.ua/UJRN/pemgki_2012_1_35.

https://medhub.info/. Ukrainian.

9. Medicines: Morion database. [Electronic resource]. Available from: www.morion.kiev.ua. Ukrainian.

10. Hoey GB, Smith KR. Chemistry of X-ray contrast media. In: Sovak M, ed. Radiocontrast agents. Handbook of Experimental Pharmacology. New York: SpringerVerlag; 1984. Vol. 73; p. 123-6.

11. Sergeev PV, Polyaev YuA, Yudin AL, Shimanovskij NL. Contrast agents [Контрастные средства]. Moscow: Izvestiya; 2007. Russian.

12. Sidorova EE, Karmazanovsky GG. Comparative study of contrasting properties of non-ionic X-ray contrast drugs yogeksol-350 and yversol-350 in spiral computed tomography in patients with hypercontrast formation of the liver [Сравнительное исследование контрастирующих свойств неионных рентгеноконтрастных препаратов йогексол-350 и йоверсол-350 при спиральной компьютерной томографии у пациентов с гиперконтрастными образованиями печени]. Meditsinskaya vizualizatsiya. 2007;5: 106-17. Russian.

13. Khokhlov AL, Kabanov AV, Kozlova OG. The safety of X-ray contrast agents: a focus on safety [Безопасность рентгеноконтрастных веществах: фокус на безопасность]. Meditsinskaya vizualizatsiya. 2018;5: 94-105. Russian.

14. Kovalenko AL. Pharmacological activity of the original drugs based on 1-deoxy-1(N-methylamino)-D-glucitol [dissertation on the internet]. Saint Petersburg; 2005. [cited 2019 Oct 30]. Available from: https://www.dissercat.com/content/farmakologicheskaya-aktivnostoriginalnykh-lekarstvennykh-preparatov-na-osnove1-dezoksi-1n. Russian.

15. Kovalenko SM. The choice of excipients when creating combination pills for the treatment of diabetic complications [Вибір допоміжних речовин при створенні комбінованих таблеток для лікування діабетичних ускладнень]. Problemy ekolohichnoi ta medychnoi henetyky i klinichnoi imunolohii. 2012;1: 333-40. Available from: http://nbuv.gov.ua/UJRN/pemgki_2012_1_35. Ukrainian.

ISSN 2312-0967. Pharmaceutical review. 2020. № 1 
Фармацевтичний менеджмент, маркетинг та логістика

Pharmaceutical management, marketing and logistics

\section{Відомості про авторів}

Пальчевська Т. А. - канд. хім. н., доцент кафедри промислової фрармації, Київський національний університет технологій та дизайну, Київ, Україна. E-mail: palchevska_knutd@ukr.net, ORCID 0000-0002-7101-4317

Баула О. П. - канд. хім. н., доцент кафедри промислової фрармації Київський національний університет технологій та дизайну Київ, Україна, E-mail: baulapharma@gmail.com, ORCID 0000-0003-4305-6517

Салій О. О. - канд. фрарм. н., доцент кафедри промислової фрармації Київський національний університет технологій та дизайну Київ, Україна. E-mail: saliy.oo@knutd.edu.ua ,ORCID 0000-0001-7103-2083

Бессарабов В. І. - канд. хім. н., доцент кафедри промислової фрармації Київський національний університет технологій та дизайну Київ, Україна. E-mail: bessarabov.vi@knutd.com.ua, ORCID 0000-0003-0637-1729

Тарасенко Г. В. - канд. техн. н., доцент кафедри промислової фрармації Київський національний університет технологій та дизайну Київ, Україна. E-mail: antar_knutd@ukr.net, ORCID 0000-0002-0995-7322

Куришко Г. Г. - доцент кафедри промислової фрармації Київський національний університет технологій та дизайну Київ, Україна. E-mail: kyrushko_knutd@ukr.net, ORCID 0000-0002-2024-2088

\section{Information about the authors}

Palchevska T. A. - PhD (Chemistry), Associate Professor of the Department of Industrial Pharmacy, Kyiv National University of Technologies and Design, Kyiv, Ukraine. E-mail: palchevska_knutd@ukr.net, ORCID 0000-0002-7101-4317 Baula O. P. - PhD (Chemistry), Associate Professor of the Department of Industrial Pharmacy, Kyiv National University of Technologies and Design, Kyiv, Ukraine, E-mail:baulapharma@gmail.com, ORCID 0000-0003-4305-6517

Saliy O. O. - PhD (Pharmacy), Associate Professor of the Department of Industrial Pharmacy, Kyiv National University of Technologies and Design, Kyiv, Ukraine. E-mail: saliy.oo@knutd.edu.ua, ORCID 0000-0001-7103-2083

Bessarabov V. I. - PhD (Chemistry), Associate Professor of the Department of Industrial Pharmacy, Kyiv National University of Technologies and Design, Kyiv, Ukraine. E-mail: bessarabov.vi@knutd.com.ua, ORCID 0000-0003-0637-1729

Tarasenko H. V. - PhD (Technology), Associate Professor of the Department of Industrial Pharmacy, Kyiv National University of Technologies and Design, Kyiv, Ukraine. E-mail: antar_knutd@ukr.net, ORCID 0000-0002-0995-7322

Kuryshko H. H. - Associate Professor of the Department of Industrial Pharmacy, Kyiv National University of Technologies and Design, Kyiv, Ukraine. E-mail: kyrushko_knutd@ukr.net, ORCID 0000-0002-2024-2088 